\title{
The Metabolism of Glycyl-L-leucine in Escherichia coli
}

\author{
By NATALIE MEISLER AND SOFIA SIMMONDS \\ Department of Biochemistry, Yale University, New Haven, Connecticut, U.S.A.
}

(Received 13 August 1962)

\begin{abstract}
SUMMARY
The metabolism of glycyl-L-leucine in a leucine auxotroph of Escherichia coli strain $\mathrm{K}-12$ was investigated with respect to the bacteriostatic effect of the peptide on growth, its hydrolysis by bacterial preparations, and its uptake by resting organisms. Growth inhibition by the peptide is relatively small if the organisms used as the inocula for the growth tests are taken from actively multiplying cultures (young organisms), but is marked if the inocula consist of organisms from cultures aged in an acid-producing, poorly buffered medium; ageing in a well-buffered or neutral medium does not produce peptide-sensitive organisms. Aged organisms that are very sensitive to the peptide readily take up the compound from the external medium, both in the absence and presence of chloramphenicol. Wholecell preparations of these aged organisms do not effect the rapid hydrolysis of glycylleucine, but cell-free extracts have as much enzymic activity as cell-free extracts of young organisms. Whole-cell preparations of young organisms also have high enzymic activity. The available data suggest that the uptake of glycylleucine by young organisms is followed immediately by its hydrolysis, whereas the peptide taken up by aged (peptide-sensitive) organisms is hydrolysed only very slowly. The growth of inocula composed of organisms taken from yeast extract + peptone + agar slopes is markedly inhibited by glycylleucine. The hydrolytic activity of whole organisms taken from slopes is significantly less than that of young organisms, but disruption of slope-grown organisms to produce cell-free extracts does not lead to any significant increase in enzymic activity.
\end{abstract}

\section{INTRODUCTION}

Some years ago it was reported that a leucine-requiring auxotroph of Escherichia coli strain K-12 can utilize for growth a variety of di-, tri- and tetrapeptides containing L-leucine and glycine (Simmonds, Tatum \& Fruton, 1947; Simmonds \& Fruton, 1949). Although the final extent of growth of the auxotroph (strain 679680 ) was the same in media containing free L-leucine or an equivalent concentration of peptide-bound leucine, the peptides exerted an inhibitory effect on the initiation of growth, which increased as the initial concentration of the peptide in the medium was increased (Simmonds \& Fruton, 1949; Simmonds, Harris \& Fruton, 1951). A similar bacteriostatic effect on the initiation of growth by leucine peptides was observed with the prototroph (strain $\mathrm{k}-12$ ) and with a threonine auxotroph (strain 679) (Simmonds et al. 1951).

The bacteriostasis was evident when the leucine auxotroph was cultured either in the absence or the presence of exogenous L-leucine, so that the 'lag' time of the growth cycle always was determined by the initial concentration of inhibitory 
peptide, whilst the final extent of growth depended upon the sum of the free the peptide-bound leucine added to the medium. Of particular interest in relation to the peptide metabolism of bacteria was the observation that inocula composed of 'young organisms' (i.e. bacteria taken from a culture in a synthetic liquid medium prior to the completion of the growth cycle) showed less sensitivity to an inhibitory dipeptide (e.g. glycyl-L-leucine) than did 'slope organisms' harvested from $24 \mathrm{hr}$. slopes composed of agar, yeast extract and peptone; on the other hand, 'aged organisms' taken from the liquid medium 85-95 hr. after the culture had attained maximal growth were much more sensitive to the inhibitor.

These observations led to the conclusion that hydrolysis of the peptides is probably a required step in the utilization of peptide leucine for growth and also the mechanism for the reversal of the inhibition (Simmonds et al. 1951). It was suggested that the decreased inhibitory effect observed with inocula composed of young organisms might be due to a relatively high enzymic activity in the hydrolysis of the peptides (Simmons \& Fruton, 1949). The experiments to be reported here were undertaken in an attempt to determine the validity of these hypotheses and, in particular, to study the effects of 'ageing' on the bacterial metabolism of leucine peptides such as glycyl-L-leucine.

\section{METHODS}

Organism. The leucine auxotroph used, strain 679-680, was the leucine- and threonine-requiring mutant of Escherichia coli strain K-12 described by Simmonds et al. (1947). Stock cultures were maintained on slopes of 'complete-agar': $0 \cdot 5 \%$ $(w / v)$ Difco yeast extract $+\mathbf{0} \cdot 3 \%(w / v)$ Difco peptone $+\mathbf{1 . 5} \%(w / v)$ Difco agar.

Growth tests. The procedures followed were essentially those of Simmonds, Harris \& Fruton (1951). The two basal media used were similar in composition to media $\mathbf{A}$ and $\mathrm{C}$ of Simmonds \& Griffith (1962), and differ only in nitrogen sources and buffering power: medium $\mathrm{A}$ has $\mathrm{NH}_{4}{ }^{+}$salts and 25 mu-phosphate, medium $\mathrm{C}$ has glycine and 100 mu-phosphate. In the present experiments, each basal medium also contained $0.8 \mathrm{mM}$-DL-threonine (to satisfy the requirement of strain $679-680$ for that amino acid) and was supplemented either with L-leucine or with glycyl-L-leucine in the concentrations indicated for each experiment.

Inocula consisted of bacteria taken either from $24 \mathrm{hr}$. cultures on complete-agar slopes ('slope organisms'), from $24 \mathrm{hr}$. cultures in 'complete-broth' (the yeast extract + peptone mixture in water) or from cultures in one of the basal media supplemented with $240 \mu \mathrm{M}-\mathrm{L}$-leucine. Organisms from slopes were suspended in a sterile aqueous solution of glucose $\left(40 \mathrm{mg} . / \mathrm{ml}\right.$.) at a concentration of $c .2 \times 10^{7}$ cells/ $\mathrm{ml}$. to give an inoculum suspension of optical density (i.e. absorbancy) in an Evelyn colorimeter (Minneapolis-Honeywell Regulator Co., Philadelphia, Pa.), filter no. 540. For inocula composed of organisms from liquid cultures, a portion of the culture was diluted with the sterile glucose solution to the desired optical density. Such inoculum suspensions, therefore, contained a small amount of culture fluid; at most this contaminating fluid was $0.3 \mathrm{ml} . / \mathrm{ml}$. of inoculum suspension. Samples of 'young organisms' were removed from the liquid cultures at the time of approximately half-maximal growth, i.e. c. $30 \mathrm{hr}$. after inoculation with slope organisms, and samples of 'aged organisms' at $c .100 \mathrm{hr}$. after attainment of maximal growth, i.e. about $140 \mathrm{hr}$. after inoculation. 
Growth of cultures, which consisted of a final volume of $10 \mathrm{ml}$. of medium containing c. $10^{7}$ cells (added as the inoculum suspensions described above), was measured by periodic optical density determinations (Evelyn colorimeter, filter no. 540). Cultures were incubated at $25^{\circ}$ either statically or on a shaker, as specified for each experiment. The times required for cultures to reach half-maximal optical density $\left(t_{t}\right)$ in the presence of each test compound were determined, and the extent of peptide inhibition, expressed as $\Delta t_{\frac{1}{2}}$, was estimated by subtracting $t_{\frac{1}{2}}$ for leucine from $t_{1}$ for the equimolar concentration of glycyl-L-leucine.

Hydrolysis experiments. Strain 679-680 organisms were grown at $25^{\circ}$ either on slopes of complete agar for $24 \mathrm{hr}$., or in $500-1000 \mathrm{ml}$. of medium A containing $1 \mathrm{~mm}-\mathrm{L}-\mathrm{leucine}$ for the time required to produce young or aged organisms. The liquid cultures were incubated statically or on a shaker as specified for each experiment, and the bacteria were collected by centrifugation $(2500 \mathrm{rev} . / \mathrm{min}$., room temperature), washed twice with $0.9 \%(\mathrm{w} / \mathrm{v}) \mathrm{NaCl}$ solution and then resuspended in the saline solution. Organisms were removed from slopes on cotton swabs and suspended in $0.9 \%$ saline. The final saline suspensions contained an amount of fresh organisms equivalent to approximately $1 \mathrm{mg}$. dry weight $/ \mathrm{ml}$. For the preparation of cell-free extracts, the whole bacteria were frozen and crushed in a Hughes press. The crushed material was suspended in saline (the resulting suspension contained the equivalent of $1 \mathrm{mg}$. dry weight of whole bacteria $/ \mathrm{ml}$.), and centrifuged to remove cell debris. Lyophilized preparations also were made from frozen whole organisms.

Complete reaction mixtures (10 $\mathrm{ml}$. final volume) consisted of glycyl-L-leucine $(2 \mathrm{~mm})$ and one of the various bacterial preparations in a solution ( $\mathrm{pH} 7 \cdot 1$ ) containing $\mathrm{Na}_{2} \mathrm{SO}_{4}$, phosphate, $\mathrm{MgSO}_{4}$, and 'trace elements' in the concentrations at which these salts are present in basal medium A. Thus, the hydrolysis reaction medium resembled the basal growth medium except for the omission of all inorganic nitrogen compounds, asparagine and glucose. Control mixtures lacking either the dipeptide or the bacterial preparations were included in each experiment. All reaction mixtures were incubated in tightly stoppered $10 \mathrm{ml}$. volumetric flasks in a water bath at $38^{\circ}$ (other conditions as specified for each experiment). Samples $(1 \mathrm{ml}$.) were removed at zero time, and at intervals thereafter, and placed in small test tubes which were heated in a boiling water bath for $10 \mathrm{~min}$. and then centrifuged. Samples $(0 \cdot 1 \mathrm{ml}$.) of the deproteinized mixtures were analysed, in triplicate, for amino acid nitrogen by the photometric ninhydrin method to measure the extent of hydrolysis of the dipeptide (Schwartz \& Engel, 1950; Meinhart \& Simmonds, 1955). Equimolar concentrations of glycylleucine, leucine, and glycine have approximately equal colourvalues in this ninhydrin analysis. Standard curves were prepared with mixtures of dipeptide + glycine + leucine in the proportions expected for from 0 to $100 \%$ hydrolysis.

When $\mathrm{NH}_{3}$ production was measured, 0.4 or $0.5 \mathrm{ml}$. of a deproteinized mixture was diluted with water to $10 \mathrm{ml}$. and treated with Nessler reagent (Seligson \& Seligson, 1951); the dipeptide present in the sample does not interfere with the Nesslerization reaction.

For paper chromatographic examination of the deproteinized mixtures, $0 \cdot 1 \mathrm{ml}$. samples were spotted on paper; the developing solvent (ascending) was $n$-butanol + pyridine + water (2:1:1, by vol.). $R_{F}$ values were: leucine, 0.52 ; glycylleucine, $0 \cdot 27$; 
glycine, $0 \cdot 08$. When glycyl- $\left[{ }^{14} \mathrm{C}\right] \mathrm{L}$-leucine was the substrate, the areas on the paper chromatograms corresponding to the peptide and to leucine were eluted, and their ${ }^{14} \mathrm{C}$-contents determined. The extent of hydrolysis was calculated from both the amount of labelled peptide that disappeared and the amount of labelled leucine that was formed.

Uptake experiments. The bacteria were grown on complete-agar slopes or in medium A supplemented with leucine as described in the preceding section. Young organisms were prepared in shaken cultures, aged organisms in static cultures. The organisms were collected by centrifugation in the cold, washed twice with cold distilled water to free them of contaminating threonine (and leucine), and resuspended in sufficient cold basal medium $\mathbf{A}$ (devoid of threonine and any leucinecontaining compound) to provide a suspension of optical density $0 \cdot 09-0 \cdot 10$ (equivalent to a wet-cell volume of about $0.5 \mu \mathrm{l}$., and a concentration of $100 \mu \mathrm{g}$. dry weight of bacteria, per ml.). This suspension was kept at $25^{\circ}$ for $30 \mathrm{~min}$. prior to the addition of leucine or glycylleucine. The subsequent procedure was that of Levine \& Simmonds (1960) except for the following modifications: (a) all incubations were at $\mathbf{2 5}^{\circ}$, and the mixtures containing aged organisms were incubated statically rather than on a shaker; $(b)$ chloramphenicol was used at a concentration of $100 \mu \mathrm{g} . / \mathrm{ml}$. of medium; $(c) 2 \mathrm{ml}$. samples of the test cultures were removed for collection of the organisms and ${ }^{14} \mathrm{C}$-analysis by the 'Millipore method'. To calculate the m $\mu$ moles of compound in the organisms collected at any specified time, the observed radioactivity was corrected by subtraction of the radioactivity in the zero-time sample. Zero-time samples had $0 \cdot 6-1 \cdot 8 \%$ of the ${ }^{14} \mathrm{C}$-content of $2 \mathrm{ml}$. of media. In experiments with labelled compounds at a concentration of $100 \mu \mathrm{M}$, the maximal error of the values given (for the organisms collected from $2 \mathrm{ml}$. of culture) is estimated to be $\pm 0.05 \mathrm{~m} \mu$ mole; with labelled compounds at $50 \mu \mathrm{M}$, this error is $\pm 0.03 \mathrm{~m} \mu \mathrm{mole}$. The isotope content of whole organisms, expressed as $m \mu$ moles of labelled test compound in the organisms from a $2 \mathrm{ml}$. sample of culture, divided by the $\mathrm{mm}$ concentration of test compound in the 'uptake medium' is a measure of the extent to which the test compound is 'concentrated' by the bacterial cells.

Test compounds. Uniformly labelled $\left[{ }^{14} \mathrm{C}\right] \mathrm{L}$-leucine (purchased from NuclearChicago Corporation, Chicago, Ill.) and the glycyl-[14 $\mathrm{C}] \mathrm{L}$-leucine prepared (Vaughan \& Osato, 1952) from it were diluted with the corresponding unlabelled compounds to the desired specific activities. Unlabelled amino acids and glycyl-L-leucine were gifts from Dr Joseph S. Fruton.

\section{RESULTS}

Growth tests. Experiments were carried out to determine whether the extent to which the growth of the leucine auxotroph is inhibited by glycylleucine depends on the conditions under which the growth tests are made as well as on the 'type' of organisms used as the inocula (Table 1). The results indicate that inocula composed of a given 'cell-type' prepared under a given set of conditions (e.g. slope organisms) show approximately the same relative growth responses to leucine and glycylleucine ( $\Delta t_{1}$ values) whether these responses are measured during static or shaken incubation. That the more highly aerobic conditions produced by shaking does not influence the results of the growth tests is shown also by the experiment in which slope organisms tested under $\mathbf{N}_{2}$ were found to behave just like slope organisms tested in air. 


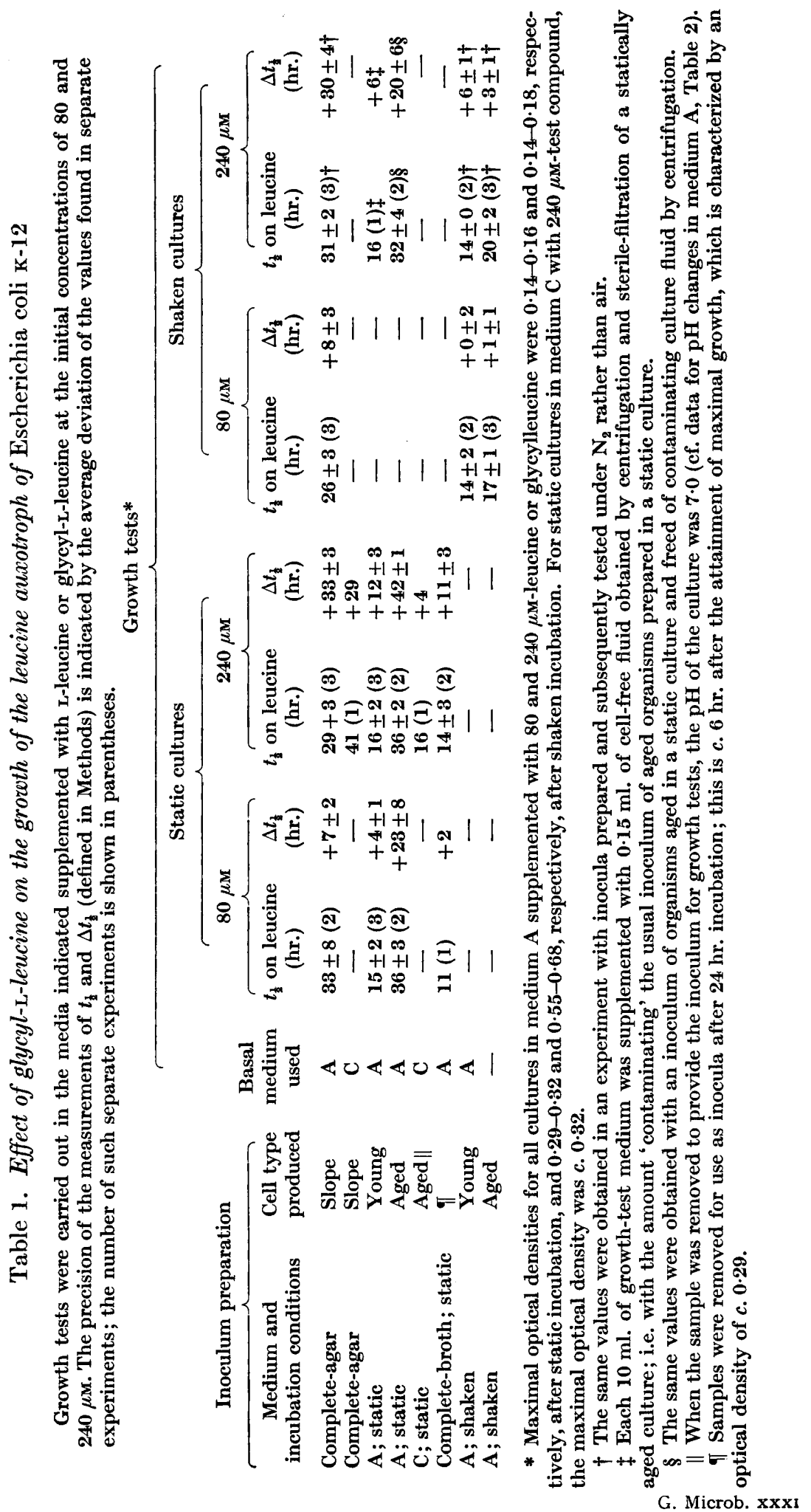


The conditions established by shaking or static incubation during the preparation of inocula have little significant effect on the extent to which the subsequent growth of young organisms is inhibited by the peptide. However, organisms aged in shaken cultures of medium A lack the high sensitivity to glycylleucine that is a characteristic property of cells aged in static cultures (cf. lines 8 and 4, Table 1).

\title{
Table 2. Production of sensitivity to glycyl-L-leucine in the leucine auxotroph of Escherichia coli K-12
}

\begin{abstract}
Organisms from a complete-agar slope were inoculated into a series of tubes containing $10 \mathrm{ml}$. of medium A supplemented with $240 \mu \mathrm{M}$-L-leucine and into two tubes of this medium supplemented with $240 \mu \mathrm{M}$-glycyl-t-leucine. At each 'incubation time' shown, a sample was removed from one of the cultures growing on leucine to serve as the inoculum for a second growth test in the same types of media, and the $\mathrm{pH}$ of the remaining culture was measured. Values for $t_{\frac{1}{b}}$ and $\Delta t_{\frac{1}{2}}$ were determined as described in Methods.
\end{abstract}

Inoculum preparation

\begin{tabular}{|c|c|c|c|c|c|c|c|}
\hline \multirow{2}{*}{$\begin{array}{c}\text { Medium and } \\
\text { incubation } \\
\text { conditions }\end{array}$} & \multirow{2}{*}{$\begin{array}{l}\text { Incuba- } \\
\text { tion } \\
\text { time } \\
\text { (hr.) }\end{array}$} & \multirow[b]{2}{*}{$\begin{array}{l}\text { Culture } \\
\text { optical } \\
\text { density }\end{array}$} & \multirow[b]{2}{*}{$\begin{array}{c}\text { Culture } \\
\text { pH* }\end{array}$} & \multirow[b]{2}{*}{$\begin{array}{l}\text { Cell-type } \\
\text { produced }\end{array}$} & \multicolumn{3}{|c|}{ Growth-test response } \\
\hline & & & & & $\begin{array}{l}\text { Incubation } \\
\text { conditions }\end{array}$ & $\begin{array}{l}t_{1} \text { on } \\
\text { leucine } \\
\text { (hr.) }\end{array}$ & $\begin{array}{r}\Delta t_{1} \\
(\mathrm{hr} .)\end{array}$ \\
\hline Complete-agar & 24 & - & - & Slope & Static & 34 & +29 \\
\hline \multirow[t]{5}{*}{ A ; static } & 82 & 0.07 & $6 \cdot 4$ & Young & Static & 18 & +9 \\
\hline & 47 & $0 \cdot 16$ & $5 \cdot 6$ & - & Static & 17 & +8 \\
\hline & 102 & 0.14 & $5 \cdot 3$ & - & Static & 18 & +6 \\
\hline & 127 & $0 \cdot 13$ & $5 \cdot 4$ & - & Static & 26 & +11 \\
\hline & 153 & $0 \cdot 15$ & $5 \cdot 5$ & Aged & Static & 47 & +31 \\
\hline Complete-agar & 24 & - & - & Slope & Shaken & 22 & +25 \\
\hline \multirow[t]{5}{*}{ A; shaken } & 24 & 0.29 & $6 \cdot 2$ & Young & Shaken & 15 & +6 \\
\hline & 40 & 0.56 & $5 \cdot 8$ & - & Shaken & 16 & +5 \\
\hline & 98 & 0.59 & $6 \cdot 4$ & - & Shaken & 19 & +4 \\
\hline & 119 & 0.50 & $6 \cdot 1$ & - & Shaken & 21 & +2 \\
\hline & 146 & 0.56 & $6 \cdot 5$ & Aged & Static & 15 & +5 \\
\hline
\end{tabular}

* Prior to inoculation with slope organisms, the medium had a pH of 6.5.

The effect observed when cultures are shaken during the ageing process is not a result of increased aeration, because organisms from a culture aged under $\mathrm{N}_{2}$ on a shaker are no more sensitive to the peptide than are organisms from an aerobic culture aged whilst shaking. Rather, the effect of shaking during the ageing process appears to be related to its effect on the $\mathrm{pH}$ of the culture. Indeed, the development of the marked sensitivity to the peptide requires prolonged exposure of the organisms to an acid medium, about $\mathrm{pH} 5 \cdot 5$ (Table 2 ). This also explains why organisms aged in static cultures of the well-buffered medium $\mathrm{C}$ (Table 1 ) behave like young organisms rather than like organisms aged in static cultures of the poorly buffered medium A. It should be noted that medium $\mathrm{C}$ per se does not prevent inhibition of growth by the peptide when the inoculum consists of slope organisms.

Organisms taken from complete-broth cultures resemble young organisms, rather than slope organisms, indicating that the types of bacteria produced during a $24 \mathrm{hr}$. incubation period in broth and on the 'broth + agar' mixture may differ as widely as do young and aged organisms from stationary cultures in the much simpler synthetic medium A. As will become evident from the subsequent discussion, this 
similarity between slope and aged organisms is seen only in the growth tests, for these two types of cells differed significantly in other tests.

Hydrolysis experiments. To determine the relative peptide-splitting ability of bacteria grown under different conditions, a study was made using freshly harvested whole organisms and cell-free extracts prepared from them.

\title{
Table 3. Hydrolysis of glycyl-1-leucine by whole-cell preparations of the leucine auxotroph of Escherichia coli $\mathrm{k}-12$
}

\begin{abstract}
Complete reaction mixtures contained 2 mM-peptide and the specified amount of bacterial nitrogen (determined by micro-Kjeldahl analysis) in the form of freshly harvested organisms. Data used to estimate ' $\%$ hydrolysis observed' were obtained by the photometric ninhydrin procedure. The values are, at best, minimal ones because no corrections were made for the loss of glycine that occurs, via deamination, during the longer incubation periods.
\end{abstract}

Preparation of organisms

$\overbrace{\begin{array}{c}\text { Growth } \\ \text { conditions }\end{array}}^{\begin{array}{c}\text { Cell type } \\ \text { produced }\end{array}} \begin{gathered}\begin{array}{c}\text { reaction } \\ \text { mixture })\end{array} \\ \text { mix. } / \mathrm{ml}\end{gathered}$

Static Young $\quad 32$

Shaken Young

Static Aged*

Shaken

Aged*

Shaken

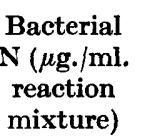

29

37

32

20

$\begin{array}{ll}\text { Young } & 20 \\ \text { Slope } & 21\end{array}$

\begin{tabular}{|c|c|c|c|c|}
\hline \multicolumn{5}{|c|}{$\%$ Hydrolysis observed } \\
\hline \multicolumn{5}{|c|}{ Mixtures incubated in static flasks for: } \\
\hline 2 hr. & $6 \mathrm{hr}$. & $15 \frac{1}{2} \mathrm{hr}$. & $18 \mathrm{hr}$. & $24 \mathrm{hr}$. \\
\hline 14 & 36 & & 70 & 63 \\
\hline 13 & 38 & 53 & 60 & 65 \\
\hline $\mathbf{0}$ & $\mathbf{0}$ & & 12 & 10 \\
\hline $\mathbf{0}$ & 10 & 20 & 26 & 38 \\
\hline \multicolumn{5}{|c|}{ Mixtures incubated in shaken flasks for: } \\
\hline $\begin{array}{c}2 \mathrm{hr} . \\
26\end{array}$ & $\begin{array}{c}6 \mathrm{hr} . \\
42\end{array}$ & $\begin{array}{c}12 \frac{1}{2} \mathrm{hr} . \\
50\end{array}$ & $\begin{array}{c}18 \frac{1}{2} \mathrm{hr} \\
52\end{array}$ & $\begin{array}{c}24 \mathrm{hr} . \\
50\end{array}$ \\
\hline 4 & 15 & 22 & 22 & 12 \\
\hline
\end{tabular}

* 'Aged cells' listed on lines 3 and 4 came from the cultures used to provide samples of 'young cell' listed on lines 1 and 2 , respectively.

Whole-cell preparations of young organisms were found to hydrolyse glycyl-Lleucine rapidly; and young organisms taken from static and shaken cultures have the same activity (Table 3 ). However, shaking of the hydrolysis reaction mixtures causes an approximate doubling of the initial (first $2 \mathrm{hr}$.) rate of hydrolysis over that observed in static mixtures. Additional experiments with young organisms (in which samples of the reaction mixtures were removed for analysis at hourly intervals) indicated that this rapid rate is maintained for about $4 \mathrm{hr}$. in shaken mixtures; under static conditions, the initial (slower) rate is maintained for at least $6 \mathrm{hr}$.

The fact that, even after $24 \mathrm{hr}$., the observed extent of hydrolysis does not reach $100 \%$ is due to the deamination of the free glycine that accumulates during the hydrolysis. Such deamination occurs very slowly, e.g. in the presence of $\mathbf{2} \mathbf{m m -}$ glycine, the amino acid is deaminated by whole organisms providing $20-40 \mu \mathrm{g}$. of bacterial nitrogen $/ \mathrm{ml}$. of reaction mixture at an initial rate of $c .2 \% / \mathrm{hr}$. (unpublished, S. Simmonds and J. Pascale). Valid comparisons of the hydrolytic action of various cell types may be based on the data obtained by the photometric ninhydrin procedure for the initial $6 \mathrm{hr}$. incubation period. This was established in experiments similar to those in Table 3 but with glycyl- $\left[{ }^{14} \mathrm{C}\right]_{\mathrm{L}}-\mathrm{leucine}$ as the substrate. Samples of the reaction mixtures were taken at intervals and analysed by the ninhydrin method and by paper chromatography followed by ${ }^{14} \mathrm{C}$-measurements. In an experi- 
ment with young organisms, the percentage hydrolysis at $2,6,11,19$ and $24 \mathrm{hr}$. was $25,48,74,90$, and $89 \%$, respectively, by ${ }^{14} \mathrm{C}$-analysis and $20,46,74,80$ and $76 \%$ respectively, by ninhydrin analysis. With aged organisms, samples at 2, 6, 11 , 21 and $24 \mathrm{hr}$. showed 2, 2, 4, 19 and $17 \%$ hydrolysis by the ${ }^{14} \mathrm{C}$-method, and 0, 0, 0 , 5 and $6 \%$ hydrolysis by the ninhydrin method.

Whole-cell preparations of slope organisms and of organisms aged in static cultures of medium A lack the high enzymic activity of young organisms, but organisms aged in shaken cultures show more peptidase activity than those aged in static cultures (Table 3).

\section{Table 4. Hydrolytic activity of whole-cell preparations and cell-free extracts of the leucine auxotroph of Escherichia coli $\mathrm{k}-12$}

\footnotetext{
'Young cells' were from a shaken culture and 'aged cells' from a static culture. Each washed whole-cell preparation was divided into two equal portions, one of which was tested directly and the other used to prepare the cell-free extract. Reaction mixtures containing aged-cell preparations were incubated statically; the other mixtures were shaken. Other procedures were as noted in Table 3.
}

\begin{tabular}{|c|c|c|c|c|c|c|c|c|}
\hline \multirow{2}{*}{$\begin{array}{l}\text { Cell type and } \\
\text { preparation used }\end{array}$} & \multirow{2}{*}{$\begin{array}{c}\text { Bacterial N } \\
(\mu \mathrm{g} . / \mathrm{ml} . \\
\text { reaction } \\
\text { mixture })\end{array}$} & \multicolumn{7}{|c|}{$\%$ Hydrolysis observed after: } \\
\hline & & $2 \mathrm{hr}$. & $6 \mathrm{hr}$. & $11 \mathrm{hr}$. & $14 \mathrm{hr}$. & $18 \mathrm{hr}$. & $21 \mathrm{hr}$. & $23 \mathrm{hr}$. \\
\hline Aged $\left\{\begin{array}{l}\text { cells } \\
\text { extract }\end{array}\right.$ & $\begin{array}{r}13 \\
7\end{array}$ & $\begin{array}{r}4 \\
14\end{array}$ & $\begin{array}{r}6 \\
42\end{array}$ & - & 16 & $\begin{array}{r}6 \\
68\end{array}$ & $\begin{array}{r}5 \\
65\end{array}$ & - \\
\hline Aged $\left\{\begin{array}{l}\text { cells } \\
\text { extract }\end{array}\right.$ & $\begin{array}{l}91 \\
40\end{array}$ & $\begin{array}{r}2 \\
48\end{array}$ & $\begin{array}{l}22 \\
87\end{array}$ & - & $\begin{array}{l}74 \\
98\end{array}$ & $\begin{array}{l}47 \\
94\end{array}$ & - & $\begin{array}{r}52 \\
100\end{array}$ \\
\hline Young, extract & $\mathbf{3 5}$ & 48 & 100 & - & 100 & $78 *$ & - & $26^{*}$ \\
\hline Slope $\left\{\begin{array}{l}\text { cells } \\
\text { extract }\end{array}\right.$ & $\begin{array}{r}12 \\
4\end{array}$ & $\begin{array}{l}14 \\
10\end{array}$ & $\begin{array}{l}20 \\
16\end{array}$ & $\begin{array}{l}30 \\
24\end{array}$ & - & - & - & - \\
\hline Slope $\left\{\begin{array}{l}\text { cells } \\
\text { extract }\end{array}\right.$ & $\begin{array}{l}81 \\
18\end{array}$ & $\begin{array}{l}27 \\
33\end{array}$ & $\begin{array}{l}99 \\
71\end{array}$ & $\begin{array}{r}100 \\
96\end{array}$ & - & - & - & - \\
\hline
\end{tabular}

* Values indicate the disappearance of $0.44 \mu$ mole of free amino acid $/ \mathrm{ml}$. reaction mixture during the period from 14 to $18 \mathrm{hr}$., and $1.48 \mu$ mole from 14 to $23 \mathrm{hr}$. (based on the presence of $2 \mu$ mole of free glycine $+2 \mu$ mole of free leucine $/ \mathrm{ml}$. at $14 \mathrm{hr}$.).

When cell-free extracts were tested (Table 4), it became apparent that extracts of organisms aged in static cultures contain as much hydrolytic activity as extracts of young organisms. However, the preparation of extracts from slope organisms does not produce the marked increase in the amount of enzymic activity observed with aged organisms.

A further comparison of young and aged organisms was made using lyophilized preparations in an attempt both to circumvent any permeability barriers present in freshly harvested bacteria and to reduce the loss of free glycine by deamination (see Simmonds \& Griffith, 1962). Again, the young organisms showed significantly more hydrolytic activity than the aged organisms (Table 5). However, the activity of the lyophilized preparation of aged organisms appears to be greater than that of the fresh preparation (cf. Tables 3 and 5).

Uptake experiments. Because the results of the hydrolysis experiments might be taken as evidence that whole organisms from cultures aged statically are relatively 
Table 5. Hydrolytic activity of lyophilized preparations of the leucine auxotroph of Escherichia coli K-12

Complete reaction mixtures contained, per ml., $\mathbf{0 . 3} \mathrm{mg}$. of lyophilized organisms (from static cultures) providing $36 \mu \mathrm{g}$. and $42 \mu \mathrm{g}$. of bacterial-nitrogen as young and aged organisms, respectively. Reaction mixtures were incubated statically; other procedures as noted in Table 3. The 'corrected' $\%$ hydrolysis was calculated from the 'observed' value plus the amount of $\mathrm{NH}_{3}$ formed, based on the assumption that the sum of leucine + glycine $+\mathrm{NH}_{3}$ (in $\mu$ mole) is equal to the amount of glyeylleucine (in $\mu$ mole) hydrolysed.

\begin{tabular}{|c|c|c|c|c|c|c|}
\hline Cell type & Measurement & $2 \mathrm{hr}$. & $6 \mathrm{hr}$. & $12 \mathrm{hr}$. & $18 \mathrm{hr}$. & $24 \mathrm{hr}$. \\
\hline \multirow[t]{3}{*}{ Young } & $\begin{array}{l}\mathrm{NH}_{\mathbf{3}}(\mu \text { mole } / \mathrm{ml} .) \\
\% \text { Hydrolysis }\end{array}$ & 0 & 0 & 0.06 & 0.30 & 0.70 \\
\hline & observed & 14 & 42 & 60 & 55 & 61 \\
\hline & calculated & 14 & 42 & 63 & 70 & 96 \\
\hline \multirow[t]{3}{*}{ Aged } & $\begin{array}{l}\mathrm{NH}_{3}(\mu \text { mole } / \mathrm{ml} .) \\
\% \text { Hydrolysis }\end{array}$ & 0 & 0 & 0.02 & $\mathbf{0 . 2 4}$ & - \\
\hline & observed & $\mathbf{0}$ & 27 & 41 & 41 & - \\
\hline & calculated & $\mathbf{0}$ & 27 & 42 & 53 & - \\
\hline
\end{tabular}

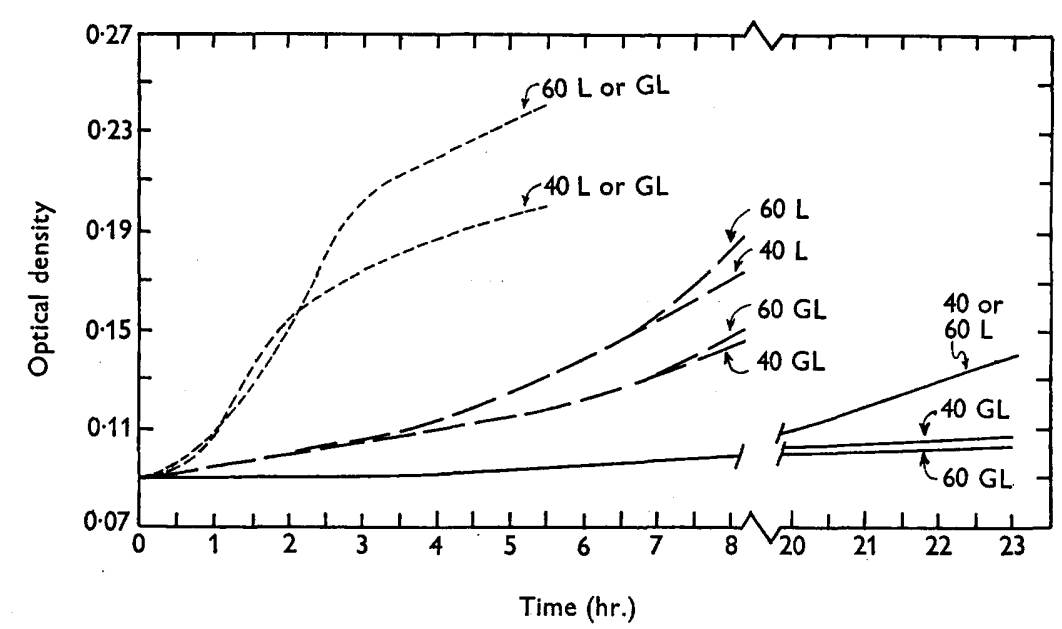

Fig. 1. Growth curves for cultures of the leucine auxotroph of Escherichia coli K-12 tested under conditions similar to those used in uptake experiments. Young organisms (dotted lines), slope organisms (dashed lines) or aged organisms (solid lines) were suspended in medium A (containing threonine), and the suspensions were supplemented with $40 \mu \mathrm{M}$ - and $60 \mu \mathrm{M}$-L-leucine (curves $40 \mathrm{~L}$ and $60 \mathrm{~L}$ ) or with $40 \mu \mathrm{M}$ - and $60 \mu \mathrm{M}$-glycyl-Lleucine (curves $40 \mathrm{GL}$ and $60 \mathrm{GL}$ ). Growth of young organisms is not delayed in the presence of 100 or $200 \mu \mathrm{M}$-peptide; with slope and aged organisms, the bacteriostatic effect increases as the peptide concentration is raised, and, at the $200 \mu \mathrm{M}$ level, there is no optical density (absorbancy) increase for the aged-organism culture in $35 \mathrm{hr}$.

impermeable to glycylleucine, the ability of these bacteria to take up the peptide was tested directly, and was compared with that of both young and slope organisms.

Before the uptake of labelled compounds could be studied, it was necessary to determine the 'sensitivity' of the bacteria to glycylleucine under conditions where the medium initially contains the very large numbers of bacteria required for the uptake experiments. Peptid concentrations of 40-200 $\mu \mathrm{M}$ were found to have no 
inhibitory effect on the growth of young organisms, but concentrations of 40-60 $\mu \mathrm{M}$ are bacteriostatic both to slope organisms and to aged organisms (Fig. 1). The initiation of growth on free leucine requires prolonged incubation when the medium contains slope organisms or organisms aged in static cultures of medium $\mathbf{A}$; young organisms begin to grow after only a short lag period (15-30 min. after the addition of leucine to an otherwise complete medium).

For the uptake experiments, the labelled leucine and glycylleucine were used at initial concentrations of 50 or $100 \mu \mathrm{M}$ in medium A devoid of threonine. Such an uptake medium presumably is incapable of supporting growth and protein synthesis because it lacks threonine. Preliminary tests indicated that it does not support growth (determined by optical density measurements), but a significant portion of the isotopic carbon taken up by the organisms may be present in the cell fraction insoluble in cold $13 \%(\mathrm{w} / \mathrm{v})$ trichloroacetic acid. Such 'protein synthesis' can be inhibited by the addition of chloramphenicol to the uptake medium (Table 6, Expts. 1 and 2). Apparently, the lack of an exogenous source of threonine, which is an essential growth factor for these bacteria, does not prevent completely the incorporation of leucine into protein when that process is not inhibited by chloramphenicol (cf. Levine \& Simmonds, 1960).

\section{Table 6. Uptake of labelled compounds by the leucine auxotroph of} Escherichia coli K-12

\begin{tabular}{|c|c|c|c|c|c|c|}
\hline \multirow[b]{3}{*}{$\begin{array}{c}\text { Expt. } \\
\text { no. }\end{array}$} & \multirow[b]{3}{*}{$\begin{array}{l}\text { Cell type } \\
\text { used }\end{array}$} & \multirow[b]{3}{*}{$\begin{array}{l}\text { Time of } \\
\text { sampling }\end{array}$} & \multicolumn{4}{|c|}{$\begin{array}{l}\text { Isotope content (m } \mu \text { moles of compound/ } \\
\text { cell-sample) }\end{array}$} \\
\hline & & & \multicolumn{2}{|c|}{ Leucine in medium* } & \multicolumn{2}{|c|}{ Glycylleucine in medium $\dagger$} \\
\hline & & & & $\begin{array}{l}\text { +Chlor- } \\
\text { amphenicol }\end{array}$ & & $\begin{array}{l}\text { +Chlor- } \\
\text { amphenicol }\end{array}$ \\
\hline 1 & Aged & $13 \mathrm{hr}$. & $4.8 \ddagger$ & $1 \cdot 4$ & - & - \\
\hline 2 & Young & $\begin{array}{l}15 \text { min. } \\
30 \text { min. }\end{array}$ & $\begin{array}{l}1 \cdot 8 \\
4 \cdot 0\end{array}$ & $\begin{array}{l}0.55 \\
0.16\end{array}$ & $\begin{array}{l}3 \cdot 3 \\
4 \cdot 9\end{array}$ & $\begin{array}{l}1 \cdot 2 \\
1 \cdot 3\end{array}$ \\
\hline 3 & Young & $\begin{array}{l}2 \text { min. } \\
4 \text { min. } \\
6 \text { min. }\end{array}$ & - & $\begin{array}{l}0.40 \\
0.69 \\
0.19\end{array}$ & - & $\begin{array}{l}0.42 \\
0.46 \\
0.60\end{array}$ \\
\hline
\end{tabular}

* Uptake media contained $100 \mu \mathrm{M}-\left[{ }^{14} \mathrm{C}\right] \mathrm{L}$-leucine of specific activity $14.7 \mathrm{counts} / \mathrm{min} . / \mathrm{m} \mu \mathrm{mole}$ in Expts. 1 and 2, and 15.6 counts/min./m $\mu$ mole in Expt. 3.

+ Uptake media contained $100 \mu \mathrm{M}$-glycyl-[ $\left[{ }^{14} \mathrm{C}\right] \mathrm{L}$-leucine of specific activity $17 \cdot 4$ and $20 \cdot 6$ counts/ min./m $\mu$ mole in Expts. 2 and 8, respectively.

$\ddagger$ Cell-fraction insoluble in cold trichloroacetic acid contained ${ }^{14} \mathrm{C}$ equivalent to $3.1 \mathrm{~m} \mu \mathrm{mole}$ of leucine.

The 13-hr. incubation period used in Expt. 1 of Table 6 was chosen because it is equivalent to the time required before the optical density of a control culture containing threonine showed a detectable rise. In the initial series of uptake experiments, measurements were made at the time corresponding to the end of the lag period of the growth cycle of each cell type in a medium containing leucine and threonine (see Fig. 1), i.e. when all organisms are equally capable of initiating growth in a complete medium. However, as the lag time for aged organisms was so long, it seemed probable that incubation of non-growing cultures with chloramphenicol for this period might cause extensive damage to the bacteria. Furthermore, 
the auxotroph often 'loses' its requirement for threonine on prolonged incubation in the absence of that amino acid. Both these factors would invalidate comparison of the aged organisms with other cell types. Consequently, it was decided to make uptake measurements only during the first 10 or $15 \mathrm{~min}$. after the first exposure of the organisms to the labelled compounds.

It should be noted that, in Expt. 2 of Table 6 where young organisms were incubated in the presence of chloramphenicol, the amount of peptide-leucine taken up at $15 \mathrm{~min}$. and at $\mathbf{3 0} \mathrm{min}$. is the same, but the amount of free leucine taken up

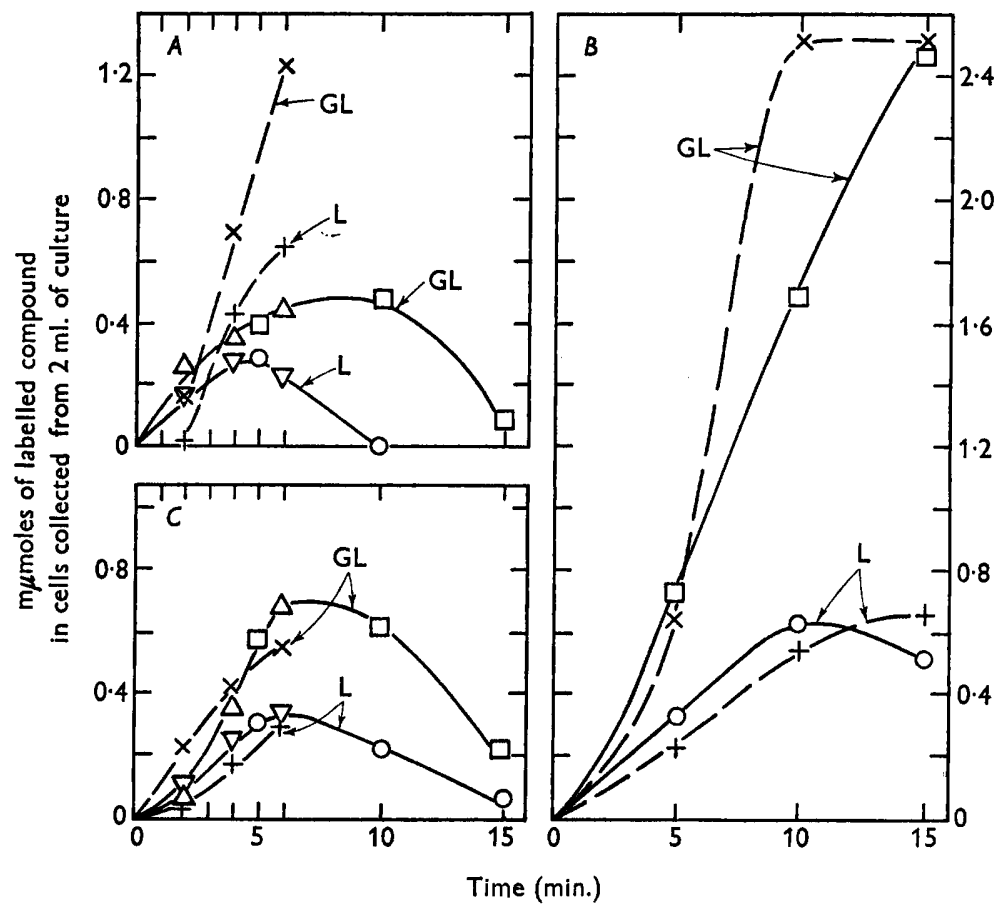

Fig. 2. Uptake of labelled L-leucine (curves L) and glycyl-L-leucine (curves GL) by the leucine auxotroph of Escherichia coli $\mathrm{k}-12$. Young organisms $(A)$, aged organisms $(B)$, or slope organisms $(C)$ were suspended in basal medium $A$ devoid of threonine in the absence (dashed lines) and presence (solid lines) of $100 \mu \mathrm{g}$. chloramphenicol/ml. The suspensions then were supplemented with $50 \mu \mathrm{M}$-labelled compound. In $A$ and $C$, data for the three sets of points: $\times$ and $+; \triangle$ and $\nabla ; O$ and $\square$; were obtained in three separate experiments. All data in $B$ are from a single experiment. The specific activity of the $\left.{ }^{14} \mathrm{C}\right]$ leucine varied from 35.9 to 41.0 counts $/ \mathrm{min} . / \mathrm{m} \mu \mathrm{mole}$, and that of the glycyl-[ $\left.{ }^{14} \mathrm{C}\right]$ leucine from $32 \cdot 2$ to $36 \cdot 9$ counts $/ \mathrm{min} . / \mathrm{m} \mu \mathrm{mole}$.

is significantly greater at $\mathbf{1 5} \mathrm{min}$. than at $\mathbf{3 0} \mathrm{min}$. Such a decrease in the isotope content of young organisms given free leucine has been observed repeatedly, and starts soon after the uptake of the amino acid has reached a maximum (Table 6 , Expt. 3 and Fig. $2 A$ ).

Experiments using $50 \mu \mathrm{M}$-test compounds (Fig. $2 \mathrm{~A}$ ), like those summarized in Table 6 for the $100 \mu \mathrm{M}$ level, show that young organisms take up glycylleucine at a rate equal to, or slightly faster than, the rate at which they take up free leucine. In uptake media containing chloramphenicol, the initial rise in isotope content is 
followed by an immediate decline when the test compound is the free amino acid, and by a 'plateau period' preceding the decline when the test compound is the dipeptide.

In general, the uptake of leucine and glycylleucine by slope organisms (Fig. 2C) resembles that by young organisms. However, the data indicate two major differences: first, the slope organisms apparently do not incorporate significant amounts of ${ }^{14} \mathrm{C}$ into protein during a short exposure to labelled test compounds in the absence of chloramphenicol. Secondly, compared to young organisms, slope organisms appear to take up somewhat more glycylleucine and to lose the ${ }^{14} \mathrm{C}$ derived from the peptide at a somewhat slower rate. Slope organisms also appear to lose ${ }^{14} \mathrm{C}$ derived from exogenous leucine at a slower rate than do young organisms.

Aged organisms differ significantly from the other types (Fig. $2 B$ ). Unlike young organisms, they do not appear to incorporate leucine into protein in the absence of chloramphenicol in $15 \mathrm{~min}$. After very long exposure (13-15 hr.) to labelled leucine (or glycylleucine) the ${ }^{14} \mathrm{C}$ content of organisms incubated in the absence of chloramphenicol (equivalent to 3-17 m $\mu$ mole leucine) may be 3-20 times higher than that of organisms incubated in the presence of the antibiotic (see also Table 1, Expt. 1). Unlike both young and slope organisms, aged organisms continue to take up leucine for at least $10 \mathrm{~min}$. after the initial exposure to the amino acid. This prolonged uptake of free leucine was observed also in a preliminary experiment in which the 5 and $10 \mathrm{~min}$. values for organisms incubated in the presence of chloramphenicol corresponded to $0 \cdot 24$ and $0 \cdot 35 \mathrm{~m} \mu$ mole of leucine, respectively.

The uptake of glycylleucine-carbon by aged organisms is much greater than that by young or slope organisms. Moreover, there appears to be no loss of isotope from the aged bacterial cells during the uptake period, as judged by the data in Fig. $2 B$, and also by data from the preliminary experiment where the 5,10 , and $15 \mathrm{~min}$. values corresponded to $0.41,0.83$ and $1.58 \mathrm{~m} \mu$ mole of labelled compound respectively.

\section{DISCUSSION}

Whole-cell preparations of the leucine auxotroph of Escherichia coli strain k-12 that consist of organisms grown on complete-agar slopes for $24 \mathrm{hr}$. or aged for several days in static cultures of an acidified synthetic medium lack the high hydrolytic activity toward glycyl-L-leucine shown by young organisms. The low peptidase activity is paralleled by a marked sensitivity to the bacteriostatic effect of the peptide on the initiation of growth when the growth medium contains glycylleucine in place of leucine. As might be expected from their relatively better growth response, organisms aged in shaken cultures (whose $\mathrm{pH}$ does not fall below $c$. $\mathrm{pH} \mathrm{6}$ ) show a greater peptidase activity than organisms aged in static cultures. Thus, ageing in the static liquid cultures would appear to be accompanied by the same changes in the metabolic capabilities of whole bacteria that characterize growth on the slopes, but the changes seem to take place at a faster rate when the organisms are closely packed on the surface of a slope.

The similarity between slope and aged organisms no longer is evident when peptidase activity is measured using cell-free extracts. The amount of activity extracted from slope organisms is approximately equal to that of the whole bacteria, whilst the activity in the extracts of aged organisms is markedly greater than that 
demonstrable in whole-cell preparations. Although the inability of slope organisms to grow readily on glycylleucine may result from their relatively low peptidase activity, a similar explanation cannot be offered for the poor growth of aged organisms.

Failure to detect high peptidase activity in whole-cell preparations of aged organisms might be attributed to one, or both, of two factors: either the whole bacteria may be relatively impermeable to the dipeptide (i.e. lack the ability to take up glycylleucine from the medium) or the bacterial cells may contain a constituent which inhibits the action of the hydrolytic enzyme in vivo but whose inhibitory effect is lost during the preparation and testing of the extracts. The data obtained in the uptake experiments indicate that aged organisms do not have a 'permeability barrier' which prevents the exogenous peptide from reaching the interior of the cells and which is eliminated when the cell extracts are made. Indeed, the existence of such a permeability barrier is unlikely because glycylleucine has a bacteriostatic effect on the leucine auxotroph cultured in the presence of free leucine, and on other Escherichia coli strains that do not require an exogenous source of either leucine or glycine for growth. Presumably, the peptide must be taken up by these bacteria in order for it to inhibit their growth. The inability of whole-cell preparations of aged organisms to catalyse the hydrolysis of the peptide seems, therefore, to be related to the presence of a cell constituent that is produced during the ageing process and that exerts an inhibitory effect upon the peptidase within the intact bacterial cells. Further evidence in support of this hypothesis has been obtained in preliminary experiments in which 'heated extracts' of aged organisms were prepared by centrifugation of a suspension of whole bacteria in $0.9 \% \mathrm{NaCl}$ solution that had been heated at $100^{\circ}$ for $10 \mathrm{~min}$. Addition of this extract to reaction mixtures containing either whole young organisms or the usual cell-free extracts of aged organisms caused a significant decrease in the initial rate of glycylleucine hydrolysis.

All three types of organisms readily accumulateleucine-carbon during the 5-10 min. following the initial exposure of the bacteria to labelled leucine or glycylleucine. The differences observed in the uptake experiments with the three cell types may be related directly to their respective metabolic states at the time of testing. Thus, young organisms are capable of initiating growth almost immediately upon resuspension in a complete growth medium (i.e. a medium containing threonine and leucine). In a threonine-deficient medium containing chloramphenicol, such organisms accumulate ${ }^{14} \mathrm{C}$ from leucine for only a short time, after which the ${ }^{14} \mathrm{C}$-content of the organisms falls rapidly. One possible explanation for the drop is suggested by the finding of Cohen \& Rickenberg (1956) that the $\left[{ }^{14} \mathrm{C}\right]$ valine concentrated by non-growing organisms of Escherichia coli is displaced by isoleucine and leucine. In agreement with this observation, we have found the amount of labelled carbon from exogenous leucine (or glycylleucine) which is taken up by young cells to be reduced about $50 \%$ when the uptake medium also contains L-isoleucine. Consequently, there may occur a 'displacement' of the labelled leucine taken into the bacterial cells by the unlabelled isoleucine and valine that is formed within the cells from the glucose and $\mathrm{N}$-sources in the uptake medium.

It is reasonable to assume that the intracellular cleavage of the dipeptide taken up by the young organisms yields free leucine and this subsequently is lost from the 
bacterial cells like the cellular leucine derived directly from the free leucine of the medium. An analogous rapid intracellular hydrolysis of dipeptides has been found with other strains of Escherichia coli (Levine \& Simmonds, 1960, 1962) and with Lactobacillus casei (Leach \& Snell, 1960); some of these bacteria take up glycine-containing peptides at a faster rate than they take up the constituent amino acids. With $L$. casei, also, resting organisms incorporate amino acid-carbon (derived from exogenous amino acids or dipeptides) into protein, and the data presented by Leach \& Snell (1960) indicate that the free amino acid in the trichloroacetic acid-soluble portion of the cells (like the isotopic-carbon in our chloramphenicol-treated organisms) first increases and later decreases in amount. A similar rapid increase followed by a drop in the size of an amino acid 'pool' was reported for the organisms in growing cultures of $\boldsymbol{E}$. coli (Bolton et al. 1957), but has not, to our knowledge, been found in non-growing cultures (Britten, Roberts \& French, 1955; Cohen \& Rickenberg, 1956; Levine \& Simmonds. 1960).

Unlike young organisms, slope organisms do not appear to incorporate leucinecarbon into protein in the absence of chloramphenicol. This may be explained by the fact that slope organisms grow much more slowly than young organisms in the complete medium, and so may be assumed to be less capable of the synthetic reactions associated with growth. Their lower synthetic capacities also would permit only a limited formation of isoleucine and valine, which would explain why slope organisms also appear to lose ${ }^{14} \mathrm{C}$ derived from leucine in the presence of chloramphenicol at a somewhat slower rate than that seen for young organisms. The ability of slope organisms to take up more peptide-carbon and to retain it better than do young organisms probably reflects their lower peptidase activity if, as suggested above, the decline in the ${ }^{14} \mathrm{C}$-content of the organisms results from the loss of leucine liberated by the intracellular hydrolysis of glycylleucine.

The carbon of free leucine is retained better by aged organisms than by the other cell types studied, although the aged organisms do not incorporate it into protein in the absence of chloramphenicol. Because aged organisms can initiate growth in a complete medium only after a very extended lag period, they may be assumed to carry out synthetic reactions at a very slow rate. This would decrease the displacement of the free leucine by isoleucine and valine formed within the bacterial cells, and also would limit the synthesis of protein. The extensive and prolonged uptake of peptide-carbon observed with aged organisms provides further support for the view that the loss of peptide-carbon from the bacterial cells occurs only after the glycylleucine has been hydrolysed. Thus, because whole-cell preparations of aged organisms do not hydrolyse glycylleucine, the bacteria continue to accumulate ${ }^{14} \mathrm{C}$, and build up intracellular concentrations of isotope far exceeding those attained in the presence of exogenous leucine. From the comparison of the hydrolytic activity and uptake response of young and aged organisms, it is clear that the failure of the latter to grow readily on glycylleucine results from the inhibition of the activity of the intracellular peptidase by some other cell constituent. On the other hand, failure of slope organisms to grow readily on the peptide appears to be a consequence of their relatively low peptidase activity. Together, these data emphasize the fact that the extent to which glycylleucine may inhibit bacterial growth depends directly upon the metabolic state and internal environment of the organisms tested. 
This study was supported in part by research grants from the National Science Foundation (G-7586) and from the National Institutes of Allergy and Infectious Diseases, United States Public Health Service (E-4257). One of the authors (N.M.) was a United States Public Health Service Graduate Training Fellow.

\section{REFERENCES}

Bolton, E. T., Britten, R. J., Cowie, D. B., Leahy, J. J., McClure, F. T. \& Roberts, R. B. (1957). Amino acid pools in Escherichia coli. Yearb. Carneg. Instn, 56, 119.

Britren, R. J., Roberts, R. B. \& French, E. F. (1955). Amino-acid absorption and protein synthesis in Escherichia coli. Proc. nat. Acad. Sci., Wash. 41, 863.

Cohen, G. N. \& Rickenberg, H. V. (1956). Concentration spécifique réversible des amino acides chez Escherichia coli. Ann. Inst. Pasteur, 91, 693.

LEACH, F. R. \& SNell, E. E. (1960). The absorption of glycine and alanine and their peptides by Lactobacillus casei. J. biol. Chem. 235, 3523.

Levine, E. M. \& Simmonds, S. (1960). Metabolite uptake by serine-glycine auxotrophs of Escherichia coli. J. biol. Chem. 235, 2902.

Levine, E. M. \& Simmonds, S. (1962). The effect of cultural conditions on growth and metabolite uptake by serine-glycine auxotrophs of Escherichia coli. J. Bact. 84, 683.

Meinhart, J. O. \& Simmonds, S. (1955). Metabolism of serine and glycine peptides by mutants of Escherichia coli strain K-12. J. biol. Chem. 216, 51.

Schwartz, T. B. \& Enger, F. L. (1950). A photometric ninhydrin method for the measurement of proteolysis. J. biol. Chem. 184, 197.

Seligson, D. \& Seligson, H. (1951). A microdiffusion method for the determination of nitrogen liberated as ammonia. J. Lab. clin. Med. 38, 324.

Simmonds, S. \& Fruton, J. S. (1949). The utilization of amino acids and peptides by mutant strains of Escherichia coli. J. biol. Chem. 180, 635.

Srmmonds, S. \& Griffirh, D. D. (1962). Metabolism of phenylalanine-containing peptide amides in Escherichia coli. J. Bact. 83, 256.

Simmonds, S., Harris, J. I. \& Fruton, J. S. (1951). Inhibition of bacterial growth by leucine peptides. J. biol. Chem. 188, 251.

Simmonds, S., TAtum, E. L. \& Fruton, J. S. (1947). The utilization of leucine derivatives by a mutant strain of Escherichia coli. J. biol. Chem. 170, 483.

VaUghan, J. R., Jr. \& Osato, R. L. (1952). The preparation of peptides using mixed carbonic-carboxylic acid anhydrides. J. Amer. chem. Soc. 74, 676. 